\title{
CLINICAL AND SEROLOGICAL EVIDENCE OF TOXOcara INFECTION IN SCHOOL CHILDREN FROM MORROPE DISTRICT, LAMBAYEQUE, PERU
}

\author{
Yrma A. ESPINOZA(1), Pedro H. HUAPAYA(1), William H. ROLDÁN(1), Susana JIMÉNEZ(1), Zhandra ARCE(2) \& Elmer LOPEZ(3)
}

\begin{abstract}
SUMMARY
The aim of this study was to estimate the frequency of human toxocariosis in a child population from Morrope district, Lambayeque, Peru. From October to December 2005, 182 school children (96 male and 86 female) were studied. Blood samples were collected for Toxocara ELISA-IgG test and hematological examination. Additionally, stool samples were collected for coproparasitological examination to check cross reactions. We found frequency of positives in $32.4 \%$ (59/182) with a significant higher proportion of positivity in male children $(p<0.00001) .71 .2 \%$ of the children with positive serology $(52$ male and seven female), were between five and 10 years old, $77.96 \%$ had respiratory symptoms, $61.02 \%$ had ocular manifestations, $38.98 \%$ had hepatic symptoms, $38.98 \%$ had mild or moderate eosinophilia, signs statistically associated with seropositivity. $83.5 \%$ of studied population had some intestinal parasite, such as: Blastocystis hominis (53.3\%), Giardia lamblia (31.3\%), Entamoeba coli (29.1\%), Entamoeba histolyticalE. dispar (1.1\%), Hymenolepis nana (5.49\%), and Ascaris lumbricoides (3.3\%), but they had not any association with serology results. The ownership of dogs or/and cats were significantly associated with seropositivity to antiToxocara antibodies although the presence of such pets within the house was not. In conclusion, clinical and serological evidence of Toxocara infection exists in the studied population.
\end{abstract}

KEYWORDS: Toxocariasis; Frequency; ELISA test; Children.

\section{INTRODUCTION}

The human toxocariasis, a serious worldwide health problem, is an accidental parasitic zoonosis due to human infection by larval stages of Toxocara canis and T. cati, they are common ascarids from dogs and cats, respectively, and considered the principal etiological agents of this syndrome ${ }^{9,21}$. Humans are infected after ingesting embryonated eggs in contaminated soil or tissues of infected paratenic hosts. The infective larvae hatch in the small intestine and migrate through somatic organs, preferably liver and eyes, and led to two different classical forms: visceral larva migrans (VLM) and ocular larva migrans (OLM) ${ }^{25}$.

Frequently, human infection with Toxocara larvae shows no clinical manifestations and evolves in an asymptomatic way. However, in some cases it can cause severe alterations such as fever, hepatomegaly, splenomegaly, respiratory symptoms, muscular pain, and anorexia, accompanied, by high eosinophilia and high titers of anti-Toxocara antibodies.

In the epidemiology of this parasitosis, ingestion of contaminated soil with embryonated Toxocara eggs is a major risk factor, though other transmission routes must be considered. A strong association between the presence of dogs and toxocariasis has been proposed, with diverse criteria regarding the real role of the contact with the dog in the transmission of this parasitosis ${ }^{16,31}$.

The method of choice for serodiagnosis is based on ELISA technique using Toxocara larvae excretion-secretion (TES) antigens ${ }^{24}$, which shows $78.3 \%$ to $100 \%$ of sensitivity and $90 \%$ to $92 \%$ of specificity ${ }^{14,15,18,24,25}$. With development of this technique, frequency studies also have been possible.

Toxocariasis prevalence is higher in tropical and developing countries and is generally associated with low socioeconomic level ${ }^{20,28}$, with rates ranging from $1 \%$ in Spain $^{22}$ to $86 \%$ in Santa Lucia $^{29}$; of $3.6 \%$ to $24.7 \%$ in Brazil $^{2,7}$; $47.5 \%$ in Colombia ${ }^{1}$; of $34.9 \%$ to $66.6 \%$ in Venezuela ${ }^{12,20}$, of $37.9 \%$ to $39 \%$ in Argentina ${ }^{3,23}$. In Peru, limited reports indicate frequency of $7.8 \%$ to $20 \%$ in rural population and of $40 \%$ in subjects with ocular suspicion ${ }^{10,11,19}$.

The goal of this study was to determine frequency of Toxocara infection in school children from Morrope district, province of Lambayeque, Lambayeque, Peru, and its association with clinical manifestations and risk factors. At the same time, we would like to 


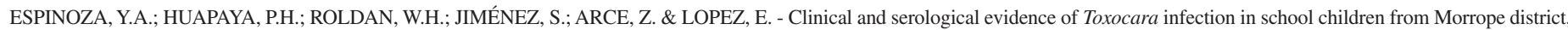
Lambayeque, Peru. Rev. Inst. Med. trop. S. Paulo, 50(2): 101-105, 2008.

determine if there could be any cross reaction between serology and presence of intestinal parasites, because they are very common in this population.

\section{MATERIAL AND METHODS}

This study was carried out from October to December 2005, in a population of school children from Morrope district, province of Lambayeque, Lambayeque, Peru. Morrope district is located at Northwest from Chiclayo City, in Lambayeque. The district has a total population of 40,356 inhabitants and a population of approximately 10,607 scholars. The central area of district (area of study) has a total population of 10,706 inhabitants with 2,827 people in school age. Kinder garden, primary and secondary schools were studied. Total population of the three schools was 259 and 182 children were selected by random sampling.

An individual record was made and the following data were registered: anamnesis data, clinical signs and symptoms (pulmonary infiltrates, bronchospasms, bronchitis, hepato and splenomegaly, abdominal pain, leucocoria, strabismus, retinitis, visual loss, convulsions and other signs of central nervous system involvement, pruritus and chronic weakness); epidemiological data and risk factors (age, sex, ownership of dogs or/and cats, their presence within home, use of public playgrounds, history of pica or geophagia) and eosinophils count: normal eosinophils $(<6 \%)$, mild $(6-10 \%)$, moderate $(11-15 \%)$ and severe $(>15 \%)$ eosinophilia. The protocol design, individual record, as well as use of biological fluid samples stocked at our institution had the approval of local ethical committee.

For hematological and immunological tests, blood samples were collected in Vacutainer tubes with and without EDTA as anticoagulant, respectively. Serum was separated by centrifugation and stored at $-20{ }^{\circ} \mathrm{C}$ until use. For coproparasitological examination, stool samples were analyzed in fresh or preserved in $10 \%$ saline-formalin solution and stored at room temperature.

Total anti-Toxocara IgG antibodies were detected by ELISA-IgG test, using TES antigens ${ }^{24}$. Previously, each serum sample was absorbed with total Ascaris suum adult extract to diminish cross reactions ${ }^{24}$. All sera were tested at 1:200 dilutions and all stages from enzyme immunoassay were performed at room temperature. The cut-off was set by the mean optical density (OD) of the negative reference serum, plus three times standard deviations. Serum samples with OD $>0.29$ (cut-off) were considered as positive. Additionally, all positive sera were serially two-fold diluted to determine antibody concentration by titration.

Hematological examination included total erythrocyte and leukocyte count, and leukocyte differential formula. Total erythrocyte and total leukocyte count was obtained by direct microscopic observation in a Neubauer chamber; leukocyte differential formula was obtained by stained-blood smear with Wright-Giemsa stain. Eosinophilia was defined as absolute eosinophils count more that 500 cells $/ \mu \mathrm{L}$, according to WILLIAMS et al. ${ }^{30}$

Coproparasitological examination was realized by direct microscopic observation in fecal smears and by rapid sedimentation technique to detect parasites that can generate cross-reactivity in the serological test.

A database was constructed in an Excel spreadsheet to record and analyze results and Chi-square test was carried out using the software Epi-Info 6.0. Statistical significance level was 5\%.

\section{RESULTS}

From 182 children, 59 were positive $(32.4 \%)$ to the ELISA-IgG test. From children with positive serology, 57.62\% (34/59) had titers of $200,22.03 \%$ (13/59) had titers of $400,16.95 \%$ (10/59) had titers of 800 , and $3.39 \%(2 / 59)$ had titers of 1600 . Association between sex and serological test show a significantly higher proportion of positivity in male children $($ Chi-square $=43.86 ; p<0.00001)$.

Ownership of dogs or/and cats showed a significant association $($ Chi-square $=16.58 ; p<0.00001)$ with positive anti-Toxocara antibodies in the sera analyzed. However, presence of pets within home was not significantly associated with seropositivity (Chi-square $=0.40$; $p=0.5261$ ). Use of public playgrounds by children showed a significant association with seropositivity to ELISA test (Chi-square $=7.11 ; p=$ 0.0076). The presence of a history of pica or geophagia also was statistically significant (Chi-square $=5.17 ; p=0.0230)$ (Table 1$)$.

Table 1

Distribution of risk factors as related to serology for toxocariasis in school children from Morrope district, Peru, 2005

\begin{tabular}{|c|c|c|c|c|c|c|c|c|}
\hline \multirow{3}{*}{ Risk factors } & & \multicolumn{6}{|c|}{ Anti-Toxocara antibodies } & \multirow{3}{*}{$p$} \\
\hline & & \multicolumn{2}{|c|}{ Positive } & \multicolumn{2}{|c|}{ Negative } & \multicolumn{2}{|c|}{ Total } & \\
\hline & & $\mathrm{N}$ & $\%$ & $\mathrm{~N}$ & $\%$ & $\mathrm{~N}$ & $\%$ & \\
\hline \multirow[t]{2}{*}{ Ownership of dogs/cats } & Yes & 58 & 39.19 & 90 & $60.81 \%$ & 148 & 100 & \multirow[t]{2}{*}{$0.0000^{*}$} \\
\hline & No & 1 & 2.94 & 33 & 97.05 & 34 & 100 & \\
\hline \multirow[t]{2}{*}{ Presence of pets within the home } & Yes & 19 & 35.85 & 34 & 64.15 & 53 & 100 & \multirow[t]{2}{*}{0.5261} \\
\hline & No & 40 & 31 & 89 & 69 & 129 & 100 & \\
\hline \multirow[t]{2}{*}{ Use of public playgrounds } & Yes & 56 & 36.36 & 98 & 63.63 & 154 & 100 & \multirow[t]{2}{*}{$0.0076^{*}$} \\
\hline & No & 3 & 10.71 & 25 & 89.29 & 28 & 100 & \\
\hline \multirow[t]{2}{*}{ History of pica or geophagia } & Yes & 13 & 21.31 & 48 & 78.69 & 61 & 100 & \multirow[t]{2}{*}{$0.0230 *$} \\
\hline & No & 46 & 38.01 & 75 & 61.99 & 121 & 100 & \\
\hline
\end{tabular}

\footnotetext{
*-Significant values; $p \leq 0.05$
} 
Association between presence of symptoms and positive serology was statistically significant (Chi-square $=32.74 ; p=0.0001$ ). The signs/ symptoms more predominant in children with positive serology were respiratory signs $(77.96 \%)$, ocular signs $(61.02 \%)$, hepatic compromise (38.98\%), abdominal pain $(30.51 \%)$ and cutaneous signs $(27.12 \%)$ (Table 2).

\section{Table 2}

Distribution of signs and symptoms as related to serology for toxocariasis in school children from Morrope district, Peru, 2005

\begin{tabular}{lcc}
\hline Signs and symptoms* & ELISA $(+)=59$ & ELISA $(-)=123$ \\
\hline Asymptomatic & 1 & 97 \\
Respiratory & 46 & 22 \\
Hepatic & 23 & 3 \\
Ocular & 36 & 10 \\
Neurological & 1 & 0 \\
Cutaneous & 16 & 14 \\
Abdominal pain & 18 & 13 \\
\hline
\end{tabular}

*Some children had more than one sign/symptom.

Association between mild or moderate eosinophilia and positive serology was statistically significant (Chi-square $=27.59 ; p<0.00001)$. From 59 children with positive serology, $33.9 \%$ had mild eosinophilia; $5.08 \%$ had moderate eosinophilia, and $61 \%$ had normal eosinophilia. Only $7.32 \%$ of children with negative serology had mild eosinophilia.

Coproparasitological analysis revealed a frequency of $83.5 \%$ (152/ 182 ) in this population: Blastocystis hominis (53.3\%), Giardia lamblia (31.3\%), Entamoeba coli (29.1\%), Entamoeba histolytica/E. dispar (1.1\%), Hymenolepis nana (5.49\%), and Ascaris lumbricoides (3.3\%). Nevertheless, the association between parasitosis and positive serology was not statistically significant (Chi-square $=1.35 ; p=0.2447$ ).

From 59 children with positive serology, $81.13 \%$ had at least one intestinal parasite: $52.54 \%$ had B. hominis, $30.5 \%$ had G. lamblia, $10.17 \%$ had $H$. nana, and $1.69 \%$ had A. lumbricoides. This case parasitized with $A$. lumbricoides had also moderated eosinophilia.

\section{DISCUSSION}

Toxocariosis is considered a helminthic zoonosis of wide geographic distribution occurring both in developed countries and in these ones with deficient sanitary, cultural, and social structures ${ }^{9}$. This parasitosis is also a poorly diagnosed disease and it is largely unknown either to health professionals or the general population.

In the present study, we observed $32.4 \%$ of frequency for antiToxocara antibodies in this child population using ELISA-IgG test, suggesting that children in study population had contact with the parasite, and developed an immune response with production of specific antibodies. This value is similar in comparison with other studies carried

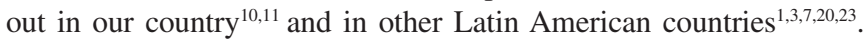

The association between male children and positive serology indicate they might be at greater risk for toxocariasis, because presence of pica, geophagia and poor hygiene behaviors might be more frequent in those children. Gender does not seem to be an important factor regarding Toxocara infection, although a higher frequency was observed in males. Several studies have shown a higher frequency of Toxocara infection in male children, which may derive from differences in the play and social behaviors of boys, resulting in increased exposure to the eggs of Toxocara sp. ${ }^{2,3,25,26,29}$. High prevalence for Toxocara serology may result from various factors, the most important of which concerns living conditions associated with urban infrastructure.

The ownership of dogs or/and cats were significantly associated with seropositivity to anti-Toxocara antibodies. Regarding presence of animals, there is controversy as to importance of contact with dogs as a risk factor for human toxocariasis. CHIEFFI et al. ${ }^{6}$ and SCHANTZ et $a l .{ }^{26}$, reported a higher frequency of infection in individuals who were in contact with dogs, however, other studies found no association between ownership or professional contact with dogs and Toxocara infection $^{13,17}$.

Presence of dogs or/and cats within home tended to be associated with risk of infection by Toxocara ${ }^{25,31}$. However, this association was not statistically significant (Chi-square $=0.40 ; p=0.5261$ ) in the present study, contradicting findings by CHIODO et al. ${ }^{8}$ and SCHANTZ et $a l .{ }^{26}$ showing significant association between seropositivity and dogs or/and cats within the home.

Use of public playgrounds is other important risk factor associated to toxocariasis infection, because canine stools are very frequent in many countries. In our study, this risk factor has significant association with Toxocara infection. It is possible that infection occurring in this population might have been brought about by inadvertent ingestion of Toxocara eggs contaminating soil of public places within the district. Limited studies in our country on the contaminated soil with Toxocara eggs revealed a frequency ranging from $30 \%$ to $80 \%^{5,19}$.

Highly significant association between signs/symptoms and positive serology indicates an evidence of Toxocara infection in this child population. However, only $39 \%$ of children with positive serology had a light or moderate eosinophilia and none had a severe eosinophilia. These data suggest that studied population could be presenting a covert toxocariasis ${ }^{21,28}$, due to unspecific clinical manifestations and the poor eosinophilia so different from classic syndromes of VLM and OLM. Children with negative serology for toxocariasis also presented symptoms, which might be due to a different etiology, i.e. intestinal parasitosis (found in $81.13 \%$ of population studied) or other unknown causes.

Respiratory symptoms was clinical feature most frequently observed in children with positive serology, and included from slight to moderated manifestations, as BUIJS et al. ${ }^{4}$ already observed in a previous study.

GLICKMAN et al. ${ }^{15}$ and SHARKEY et al. ${ }^{27}$ point out that ocular toxocariasis may be negative at ELISA test, probably due to a low concentration of circulating antibodies in this form of disease. Nevertheless, 36 out of 46 children with ocular manifestations showed positive results. According to GLICKMAN et al. ${ }^{13}$ and MAGNAVAL et $a l .{ }^{21}$ a single larva in the eye may cause serious damages, therefore, an early diagnosis is very important. 


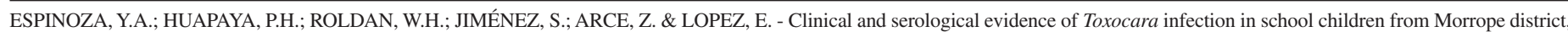
Lambayeque, Peru. Rev. Inst. Med. trop. S. Paulo, 50(2): 101-105, 2008.

Systemic infection and high frequency of intestinal parasites may occasionally be found but significant statistical association between them is lacking. As results show, more frequent parasites are protozoa and they do not cause cross reactions with ELISA test but these results suggests that studied group was exposed to soil contamination of food; this is a principal way to get Toxocara infection and represent a characteristic of our group.

The high toxocariasis frequency could be the result of various factors, but doubtless, the most important are the rural and social characteristics of Morrope district, a city with an extended area without paved streets and deficient daily cleaning, with high percentage of this population with unsatisfied basic needs and a high proportion of dogs living at home. It is well known that when dogs are present, the potential for household contamination with Toxocara eggs is high. Furthermore, deficient sanitary behaviors, climatic conditions and houses in poor neighborhoods, led to most of these children playing in close contact with soil since early ages.

Clinical and serological evidence of Toxocara infection was observed in our population. Future studies about soil contamination should be done to better assess the magnitude of this serious health problem, and community education programs should be developed to promote the social concept of a responsible pet ownership.

\section{RESUMO}

\section{Evidências clínicas e sorologicas de infecção por Toxocara em escolares do Distrito de Morrope, Lambayeque, Peru}

O propósito do presente trabalho foi estimar a freqüência da toxocaríase humana em crianças do distrito de Morrope, Lamabayeque, Perú. Nos meses de outubro a dezembro de 2005, 182 escolares (96 meninos e 86 meninas) foram estudados. Coletaram-se amostras de sangue para a análise hematológica e imunológica pelo teste de ELISAIgG-Toxocara e amostras fecais para o exame parasitológico. A freqüência geral da população foi de 32,4\% (59/182) com proporção significativamente maior de positividade nos meninos. Das crianças com resultado positivo ao teste sorológico (52 meninos e sete meninas), $71,2 \%$ tinham entre cinco e 10 anos, $77,96 \%$ apresentavam sintomas respiratórios, $61,02 \%$ apresentavam manifestações oculares, 38,98\% apresentavam moléstias hepáticas, $38,98 \%$ apresentavam suave ou moderada eosinofília e todos estes sinais foram estatisticamente associados ao resultado da sorologia. A presença de algum parasito intestinal foi observada em $83,5 \%$ da população estudada: Blastocystis hominis (53,3\%), Giardia lamblia (31,3\%), Entamoeba coli $(29,1 \%)$, Entamoeba histolyticalE. dispar (1,1\%), Hymenolepis nana (5,49\%), e Ascaris lumbricoides (3,3\%), mas estes não tiveram nenhuma associação com a sorologia. A posse de cães e gatos revelou associação estatisticamente significante com a positividade para toxocaríase embora a presença destes animais no domicílio não tenha revelado tal associação. Conclui-se que existem evidências clínicas e sorológicas de infecção por Toxocara na população estudada.

\section{REFERENCES}

1. AGUDELO, C.; VillareAL, E.; CÁCERES, E. et al. - Human and dogs Toxocara canis infection in a poor neighborhood in Bogotá. Mem. Inst. Oswaldo Cruz, 85: 75-78, 1990.
2. ALDERETE, J.M.S.; JACOB, C.M.A.; PASTORINO A.C. et al. - Prevalence of Toxocara infection in schoolchildren from the Butantã region, São Paulo, Brazil. Mem. Inst. Oswaldo Cruz, 98: 593-597, 2003.

3. ALONSO, J.M.; BOJANICH, M.V.I.; CHAMORRO, M. \& GORODNER, J.O. - Toxocara frequency in children from a subtropical city in Argentina. Rev. Inst. Med. trop. S. Paulo, 42: 235-237, 2000.

4. BUIJS, J.; BORSBOOM, G., VAN GEMUND, J.J. et al. - Toxocara seroprevalence in 5year-old elementary schoolchildren: relation with allergic asthma. Amer. J. Epidem., 140: $839-847,1994$.

5. CHÁVEZ. A.; CASAS. E.; CAJAS. J. \& VELARDE. J. - Contaminación de parques públicos con huevos de Toxocara sp. en los distritos de la provincia constitucional del Callao y del cono sur de Lima metropolitana. Rev. Invest. Vet. Peru, 11: 52-57, 2000 .

6. CHIEFFI, P.P.; UEDA, M.; CAMARGO, E.D. et al. - Contato domiciliar e profissional com cães como fatores de risco para infecção humana por larvas de Toxocara. Rev. Inst. Med. trop. S. Paulo, 30: 379-382, 1988.

7. CHIEFFI, P.P.; UEDA, M.; CAMARGO, E.D. et al. - Visceral larva migrans: a seroepidemiological survey in five municipalities of São Paulo State, Brazil. Rev. Inst. Med. trop. S. Paulo, 32: 204-210, 1990.

8. CHIODO, P.; BASUALDO, J.; CIARMELA, L. et al. - Related factors to human toxocariasis in a rural community of Argentina. Mem. Inst. Oswaldo Cruz, 101: 397-400, 2006.

9. DESPOMMIER, D. - Toxocariasis: clinical aspects, epidemiology, medical ecology, and molecular aspects. Clin. Microbiol. Rev., 16: 265-272, 2003.

10. ESPINOZA, Y.; HUAPAYA, P.; SEVILLA, C. \& HUIZA, A. - Toxocariosis humana: seroprevalencia en la población de Lima mediante la técnica de ELISA. An. Fac. Med. (Lima), 64: 228-232, 2003.

11. ESPINOZA, Y.; HUAPAYA, P.; AYLLÓN, C. et al. - Toxocariosis humana en pacientes con lesión ocular. An. Fac. Med. (Lima), 64: 247-251, 2003.

12. FELIX PIFANO, C.F.; ORIHUELA, A.R. \& DELGADO, O. - La toxocariasis humana en Venezuela, especialmente en el valle de Caracas. Gac. méd. Caracas, 96: 31-41, 1989.

13. GLICKMAN, L.T. \& CYPESS, R.H. - Toxocara infection in animal hospital employees. Amer. J. publ. Hlth, 67: 1193-1195, 1977.

14. GLICKMAN, L.; SCHANTZ, P.; DOMBROSKE, R. \& CYPESS, R. - Evaluation of serodiagnostic test for visceral larva migrans. Amer. J. trop. Med. Hyg., 27: 492 498, 1978.

15. GLICKMAN, L.T.; GRIEVE, R.; LAURIA, S.S. \& JONES, D.L. - Serodiagnosis of ocular toxocariasis: a comparison of two antigens. J. clin. Path., 38: 103-107, 1985.

16. HABLUETZEL, A.; TRALDI, G.; RUGGIERI, S. et al. - An estimation of Toxocara canis prevalence in dogs and environmental egg contamination as risk of human infection in the Marche region of Italy. Vet. Parasit., 113: 243-252, 2003.

17. JACOBS, D.E.; WOODRUFF, A.W.; SHAH, A.I. \& PROLE, J.H. - Toxocara infections and Kennel workers. Brit. med. J., 1: 51, 1977.

18. JACQUIER, P.; GOTTSTEIN, B.; STINLEGIN, Y. \& ECKERT, J. - Immunodiagnosis of toxocariasis in humans: evaluation of a new enzyme-linked immunosorbent assay kit. J. clin. Microbiol., 29: 1831-1835, 1991.

19. LESCANO, S.A.Z.; CHIEFFI, P.; PERES, B. et al. - Soil contamination and human infection by Toxocara sp. in the urban area of Lima, Peru. Mem. Inst. Oswaldo Cruz, 93: 733-734, 1998. 


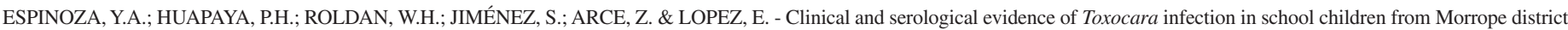
Lambayeque, Peru. Rev. Inst. Med. trop. S. Paulo, 50(2): 101-105, 2008.

20. LYNCH, N.R.; EDDY, K.; HODGEN, A.N.; LOPEZ, R.I. \& TURNER, K.J. - Frequency of Toxocara canis infection in tropical Venezuela. Trans. roy. Soc. trop. Med. Hyg., 82: 275-281, 1988.

21. MAGNAVAL, J.F.; GLICKMAN, L.T.; DORCHIES, P. \& MORASSIN, B. - Highlights of human toxocariasis. Korean J. Parasit., 39: 1-11, 2001.

22. PORTÚS, M.; RIERA, C. \& PRATS, G. - A serological survey of toxocariasis in patients and healthy donors in Barcelona (Spain). Europ. J. Epidem., 5: 224-227, 1989.

23. RADMAN, N.E.; ARCHELLI, S.M.; FONROUGE, R.D.; GUARDIS, M. \& LINZITTO, O.R. - Human toxocariosis. Its frequency in the city of La Plata. Mem. Inst. Oswaldo Cruz, 95: 281-285, 2000.

24. ROLDÁN, W.; CORNEJO, W. \& ESPINOZA, Y. - Evaluation of the dot-ELISA in comparison with standard ELISA for the immunodiagnosis of human toxocariasis. Mem. Inst. Oswaldo Cruz, 101: 71-74, 2006.

25. SCHANTZ, P.M. - Toxocara larva migrans now. Amer. J. trop. Med. Hyg., 41 (suppl. 3): 21-34, 1989.

26. SCHANTZ, P.M.; WEIS, P.E.; POLLARD, Z.F. \& WHITE, M.C. - Risk factors of toxocaral ocular larva migrans: a case- control study. Amer. J. publ. HIth, 70: 1269$1272,1980$.
27. SHARKEY, J. \& McKAY, P.S. - Ocular toxocariasis in a patient with repeatedly negative ELISA titre to Toxocara canis. Brit. J. Ophthal., 77: 253-254, 1993.

28. TAYLOR, M.R.; KEANE, C.T.; O'CONNOR, P.; MULVIHILL, E. \& HOLLAND, C. The expanded spectrum of toxocaral disease. Lancet, 1: 692-694, 1988.

29. THOMPSON, D.E.; BUNDY, D.A.P.; COOPER, E.S. \& SCHANTZ, P.M. Epidemiological characteristics of Toxocara canis zoonotic infection of children in a Caribbean community. Bull. Wld Hlth Org., 64: 283-290, 1986.

30. WILLIAMS, W.J.; BEUTLER, E.; ERSLEV, A.J. \& LICHTMAN, A.M. - Hematology. 4. ed. New York, Mc Graw-Hill, 1991. p. 1832-1833.

31. WOLFE, A. \& WRIGHT, I.P. - Human toxocariasis and direct contact with dogs. Vet. Rec., 152: 419-422, 2003.

Received: 28 May 2007

Accepted: 17 December 2007 